\title{
Interorganisational networks and proximity: an analysis of R\&D networks for cultural goods ${ }^{1}$
}

\author{
Francesco Capone - Luciana Lazzeretti
}

\begin{abstract}
Purpose of the paper: The aim of this study is to measure the impact of various dimensions of proximity to form innovation networks.

Methodology: We use a novel statistical methodology for modelling networks based on a well-studied class of models called exponential-family random graph models.

Findings: Results underline the importance of various forms of proximity in the formation of innovation networks and the potential of the novel methodology to study large and complex networks in innovation studies and R\&D management.

Research limits: The research is mainly quantitative and contributes to the debate measuring the role and importance of various forms of proximity in innovation networks. Further analysis of how firms choose their partners is needed. Moreover, the analysis should be expanded to other contexts and industries in order to be able to generalise results.

Practical implications: The work points out managerial implications in innovation studies and R\&D management in order to guide firms when choosing their partners and forming a network.

Originality of the paper: The study contributes to the debate on innovation network literature and tests a novel methodology to analyse large and complex interorganisational networks.
\end{abstract}

Key words: inter-organisational network; R\&D; proximity; cultural goods; statistical analysis

\section{Introduction}

In the debate on the new trends in innovation studies and in research and development $(\mathrm{R} \& \mathrm{D})$ management of innovation networks (Kastelle and Steen, 2014; Dagnino et al., 2015), a significant amount of attention is increasingly being devoted to the role of similarity among partners in forming new relationships or partnerships (Molina-Morales, 2015; Capone, 2016; Ahuja et al. 2009).

Scholars of social network analysis have long discussed the concept of homophily (McPherson et al., 2001), which is the tendency of two partners

1 A previous version of this work was presented at the R\&D Management Conference in Pisa in 2015 and at the International Workshop on 'Multivariate Techniques for the Analysis of Networks' with Prof. Wasserman in Salerno in 2014. We express our gratitude to the participants and to the three anonymous reviewers for their comments and advices. 
sinergie Vol. 34, N. 101, 2016

sharing some characteristics (sex, age, habits, etc.) to have a higher propensity to develop some kind of relationships (friendship, business, etc.). An opposite stream of research has focused instead on the role of differences among partners, i.e., complementarities (Love and Roper, 2009). Previously, Granovetter (1973) had stressed the importance of the links formed with different or distant partners compared to the usual network of contacts who share redundant knowledge. For this reason, firms and organisations creating links with (cognitively) distant partners is crucial for the innovation and acquisition of new knowledge.

In recent years, literature on innovation studies and innovation networks has primarily focused on the concept of proximity, and particularly on what is known as cognitive proximity or geographical proximity (Molina-Morales et al., 2014; Torre, 2011; Boschma, 2005). They especially pay attention to how the proximity between partners facilitates firms and networks' innovativeness (Muscio, 2006).

The debate on proximity is widespread, and some forms of proximity are perceived negatively as obstacles to collaborating or developing partnerships among firms and research centres or universities (Ben Letaifa and Rabeau, 2013).

Within research on innovation networks, many authors have focused on these issues, discussing as many as five to seven different forms of proximity which encourage the formation of relationships and innovation (Knoben and Oerlemans, 2006; Boschma, 2005). Generally speaking, there are at least five forms of proximity that are recognized in the literature: geographical, cognitive, organisational, institutional and social proximity.

However, most contributions on proximity and innovation networks, at this time, are mainly based on case studies or qualitative analysis (Ritter and Gemunden, 2003; Knoben and Oerlemans, 2006) with only a few quantitative exceptions (Balland, 2012; Morrison et al., 2014; MolinaMorales et al., 2014; 2015; Presutti et al., 2011; Capaldo and Petruzzelli, 2014).

The aim of this study is to analyse the role of various forms of proximity in the formation of inter-organisational innovation collaborations and, specifically, to investigate how organisations choose their partners to form innovation networks. We investigate four forms of proximity that are commonly found in the literature: geographical, cognitive, institutional and social proximity.

The work contributes to management and innovation network studies through a novel methodology for network analysis that allows to analyse large networks. It also fits into the current availability of big data to support management decisions and the analysis of competitive environments.

The methodology can be of interest in management and innovation network studies as it allows the analysis and measurement of the impact of different types of variables in complex networks composed of numerous organisations and relationships (Pina-Stranger and Lazega, 2010; Broekel and Hartog, 2013). This application is particularly useful when it is necessary to investigate multidisciplinary inter-organisational networks in high-technology industries involving several national and international firms and organisations. 
For these purposes, we adopt the novel statistical methodology of exponential random graph models (ERGMs) (Hunter et al., 2008) that allows us to investigate and provide statistical estimations of the structure of networks.

This paper focuses on innovation networks operating in the business of high-technology applied to cultural goods (HTCG) (IRPET, 2012; Lazzeretti and Capone, 2016), analysing complex networks formed by 267 actors with more than 6,500 interrelationships. The cultural goods business is particularly relevant as it is gaining interest both from academics and policy makers for financial support and policy design (IRPET, 2012; Casprini et al., 2014).

Our results underline the importance of various forms of proximity in the formation of innovation networks. Moreover, the work points out managerial implications in innovation studies and R\&D management in order to assist firms in choosing their partners and forming an innovation network (Baglieri et al., 2016).

\section{Proximity and innovation networks}

Network studies suggest that the evolution of the macro-structural characteristics of a network is driven by concurrent forces operating at the micro level (Powell and Grodal, 2005; Capaldo, 2015). This idea recalls sociological network approaches, such as those of Granovetter (1973), where knowledge sharing and partnership are related to various structural properties of individuals' positions in knowledge networks. For instance, he points out that social networks tend to be characterized by a dense subnetwork of stable relationships. Knowledge in these subnetworks tends to be homogeneous and redundant, whereas new ideas and radical innovation are achieved more frequently through new relationships with different partners.

Within innovation network studies (Bergenholtz and Waldstrøm, 2011), there is an increasing number of contributions using social network analysis (Van der Valk and Gijsbers, 2010; Sciarelli and Tani, 2014; Zanni and Pucci, 2012) and, in particular, new statistical methods to investigate network structure, thanks to big data and more powerful computers. More recent developments on quantitative analysis (Kastelle and Steen, 2014) consist in the longitudinal analysis of network evolution with simulation investigation for empirical network analysis (SIENA) software (Snijders et al., 2010) and the statistical analysis of large and complex networks with ERGM (Lusher et al. 2013; Contractor et al., 2006).

There are various examples of longitudinal studies of innovation networks. Among these, Balland (2012) investigates proximity and the evolution of collaboration networks in global satellite navigation systems in the VI Framework Programme from 2004 to 2007 and in the video game industry during the industry life cycle. Giuliani (2013) analyses the Chilean wine cluster, investigating its evolution from 2005 to 2010 and focusing on the core-periphery dynamics of the network, triadic closure and absorptive capacity. 
sinergie Vol. 34, N. 101, 2016

As regards static analysis, De Stefano and Zaccarin (2013) identify the complex structure of relationships that is at the base of knowledge and innovation diffusion between two forms of knowledge-based relations: co-authorship and co-invention. They fit a multivariate ERGM model to capture the variety and the complexity of network interactions. MolinaMorales et al. (2015) analyse a foodstuffs cluster in Spain with ERGMs, while aiming to clarify the detrimental effects and complementarities that may arise among proximity dimensions. The authors find a negative effect of cognitive and institutional proximity dimensions on the creation of linkages in advanced stages of the cluster life cycle.

ERGMs are a class of statistical models for social networks (Lusher et al., 2013; Contractor et al., 2013). They account for the presence of network ties and, thus provide a model for network structure. They help us understand how social network ties are formed, and they are particularly useful in big data networks where the network structure is difficult to investigate.

Several recent contributions on innovation networks (Knoben and Oerlemans, 2006) stress the fact that innovation is fostered by various dimensions of proximity.

In the literature there are usually at least five dimensions of proximity, in which geographical, cognitive, organizational, institutional and social proximity increase the probability of forming a relationship with others (Boschma, 2005). In other words, firms and organisations establish collaborations more easily with other organisations of the same typology, co-located in the same area, belonging to the same group, etc. In fact, in network analysis, the role of proximity in innovation and network dynamics has recently received increasing attention in $R \& D$ and innovation management (Hohberger, 2014; Capaldo and Petruzzelli, 2014; Frenkel $e t$ al., 2015) and marketing studies (Cantù, 2010; Johanson and Lundberg, 2007).

Geographical proximity and the co-location of economic activities have traditionally been considered important factors that affect competitiveness and innovation, beginning with Marshall and the concept of agglomeration economies, industrial districts and cluster debate. This is also related to the concept of tacit knowledge and its stickiness (Bathelt, 2004), particularly in regards to its importance to networks in local clusters and to competitive advantages (Tallman et al., 2004), as well as the overall (new and traditional) role of the territory in supporting competitiveness and innovation (Rullani, 2013; Dezi et al., 2011).

Cognitive proximity is a particularly significant element in promoting innovation, beginning with the concepts of absorptive capacity (Cohen and Levinthal, 1990) and knowledge bases (Nooteboom, 2000). Actors are primarily used to forming ties with other actors with whom they share the same knowledge base and competences, as interrelationships between different knowledge bases are more difficult, albeit more able to generate new knowledge and radical innovation.

Organisational proximity indicates that firms of the same corporate group are more willing to share knowledge and have an enhanced facility to innovate (Balland, 2012). 
Institutional proximity is defined as the similarity of informal constraints and formal rules shared by actors of the same typology. Usually, this aspect is related to different institutional forms as described in the triple or quadruple helix model or found in university-industry relations literature (Etzkowitz and Leydesdorff, 2000; Bonaccorsi and Piccaluga, 1994; Campanella et al., 2016).

Social proximity refers to the degree to which a common relationship can diffuse informal knowledge. It indicates that actors are usually more willing to form ties with other actors with whom they have a certain degree of trust or with whom they have shared previous R\&D projects or experiences. Social proximity refers to the degree of common relationships, where friendship and trust are central, and it is supposed to diffuse informal knowledge and facilitate collaborations (Boschma, 2005). Balland (2012) indicates that social proximity favours collaboration and that partners are more likely to interact with each other than with others. This recalls the concept of the structural mechanism of transitivity and leads to the idea of triadic closure ${ }^{2}$.

In this work, we hypothesise that four ${ }^{3}$ forms of proximity, i.e., geographical, cognitive, institutional and social proximity, have a role in the formation of innovation networks.

\section{Research design and methodological approach}

The present study departs from previous studies on the cluster of hightechnology applied to cultural goods in Florence and Tuscany (Lazzeretti et al., 2011; Lazzeretti and Capone, 2016) and focuses on the role of various forms of proximity from a static perspective.

The analysis of the role of high-technology in its application to cultural goods indicates that it is a newly emerging business for firms in various industries, such as ICT, geology, chemistry, biology, engineering, physics and optoelectronics (Casprini et al., 2014). In Tuscany, a technological cluster has been formed over time and it specialises in the restoration and enhancement of the rich local cultural heritage; it has also been recognised at the international level (Salimbeni, 2012; IRPET, 2012). Furthermore, in 2011, the Tuscan region recognised the relevance of this sector in contributing to the funding of the Technological District in Cultural Goods (TDCG) in order to support local R\&D activities and improve local governance.

Recent research has been devoted to the study of innovation in the cultural goods domain. Casprini et al. (2014) analyses business models (BMs) in HTCG, analysing 30 firms in Tuscany and their business model innovations. They find that there are several BM evolution patterns in HTCG, thus providing useful insights into this unexplored area. Lazzeretti and Capone (2016) analyse innovation networks for cultural goods, pointing out that it is a particularly interesting business, where transversal

2 See also Table 1 on the concept of triads and triadic closure.

3 We did not investigate organizational proximity, as firms of the same group were not allowed to participate in the selected research projects and it is not relevant in this specific research context. 
sinergie Vol. 34, N. 101, 2016

innovations are developed by inter-organisational networks related to several scientific domains.

Moreover, in the past years, technological districts have become the object of increasing interest of Italian authorities in relation to designing industrial policy for economic development and competitiveness (e.g., southern Italy) (Piccaluga and Cesaroni, 2003) or, specifically, technological districts in which high-technology is applied to cultural goods.

This study, in particular, focuses on the analysis of the innovation networks that were formed over a long period of time (1995-2012) through the use of ERGMs, which is a methodology used to analyse the structure of large and complex networks.

The analysis investigates co-participation in innovation policysupported R\&D projects developed for the conservation and enhancement of cultural goods and heritage. A database on funded R\&D projects has been adopted by previous research (Lazzeretti and Capone, 2016). In this paper, this database is used to develop a new analysis on the role of various forms of proximity in the formation of R\&D networks.

All of the public research centres and universities operating in the Tuscan region that are involved in cultural goods have been interviewed ${ }^{4}$.

The database contains 42 projects. The projects were funded over a span of more than 15 years through regional, national and international calls for proposals involving small and medium enterprises (SME) and large firms, research centres and universities.

For each project, comprehensive information on the participants has been collected, including total investment of the project, different (leader) roles in the project, the financial contribution received by each partner, typology, competences of each partner, etc.

\section{Innovation networks in cultural goods}

The selected projects cover a time frame of more than 15 years (1995-2012). The projects are very heterogeneous in terms of financing institutions, requested budget and number of partners involved ${ }^{5}$.

The R\&D projects have been financed by regional, national and international calls for proposals. They involve 267 actors for a total of 386 presences (an organisation may participate more than once). Most actors are Italian, representing approximately $55 \%$ of the total. However, the composition of the network has an international dimension because European actors account for about $45 \%$. In Italy, Tuscany and Florence are the most relevant locations, with more than $23 \%$ of the actors located in Florence and $18 \%$ in Tuscany. The Pisa area also plays a particularly important role with 35 players that represent approximately $9 \%$ of the total.

The analysis of the typology of actors confirms the high participation of research centres, universities and business firms. Altogether, these three groups account for over $75 \%$ of all actors, with a substantial role being

4 The group is composed of 15 actors, including six research centres affiliated with the National Centre of Research (CNR) and nine university departments.

5 See Lazzeretti and Capone (2016) for an analysis of these R\&D projects. 
played by research centres (about $31 \%$ of total), followed by firms $(20.7 \%$ ) which include both SMEs and large companies. In absolute terms, there are 68 SMEs and 12 large firms.

There are several scientific domains involved in the analysed projects. ICT for cultural heritage is the area that records the highest participation, with more than 86 actors (22.3\%). This is followed by conservation with over 52 actors (13.5\%); optoelectronics has 37 players (9.6\%); and 3D visualization records 30 actors $(7.8 \%)$. If we consider ICT together with $3 D$ visualization, they account for more than $30 \%$ of the total. Other significant areas of expertise are physics with 28 actors (7.3\%); restoration with $26(6.7 \%)$; chemistry with 23 (6\%); and museums with about 16 (4\%).

As the global network is too numerous to analyse graphically (due to the large number of nodes), Fig. 1 shows the network by considering a coparticipation to at least two projects. The full network of 267 organisations developed from the 42 analysed research projects along 15 years is presented in Appendix 1. Each node of the graph represents a firm or an organisation, while a line represents a tie between two actors, which means that those two partners co-participated in the same project(s).

The size of the nodes measures the number of ties they have in that period; therefore, larger nodes represent more central actors. The gradation of the grey colour of the nodes represents the location of the actors (Florence, Tuscany, Italy, Europe) while the shape indicates the typology (SMEs and large firms, universities, research centres).

In next section, we investigate the structure of the networks through the use of ERGMs in order to shed light on how actors have formed their innovation networks.

\section{Exponential random graph model to analyse network structure}

\subsection{Model}

The ERGM package for R, a cornerstone of the STATNET suite of packages for statistical network analysis (Hunter et al. 2008), provides tools for modelling networks based on a well-studied class of models called exponential random graph models (ERGMs) or $\mathrm{p}^{*}$ models (Wasserman and Pattison, 1996).

The ERGM package allows users to obtain approximate maximum likelihood estimates (MLEs), simulate random networks from a specified ERGM and perform graphical goodness-of-fit tests (Hunter et al., 2008).

ERGMs are based on the Markov chain Monte Carlo technique. They are a class of algorithms for sampling from probability distributions based on the construction of a Markov chain having stationary distribution as the desired distribution (Hunter et al., 2008). The state of the chain, after a certain number of steps, is then used as a sample of the desired distribution.

The aim of the ERGM is to succinctly describe the selection forces that shape the global structure of a network. In other words, the network data set may be considered similar to the response in a regression model, where the predictors consist in variables such as the propensity for firms
Francesco Capone

Interorganisational

networks and proximity:

an analysis of R\&D

networks for cultural 


\section{sinergie \\ italian journal of management Vol. 34, N. 101, 2016}

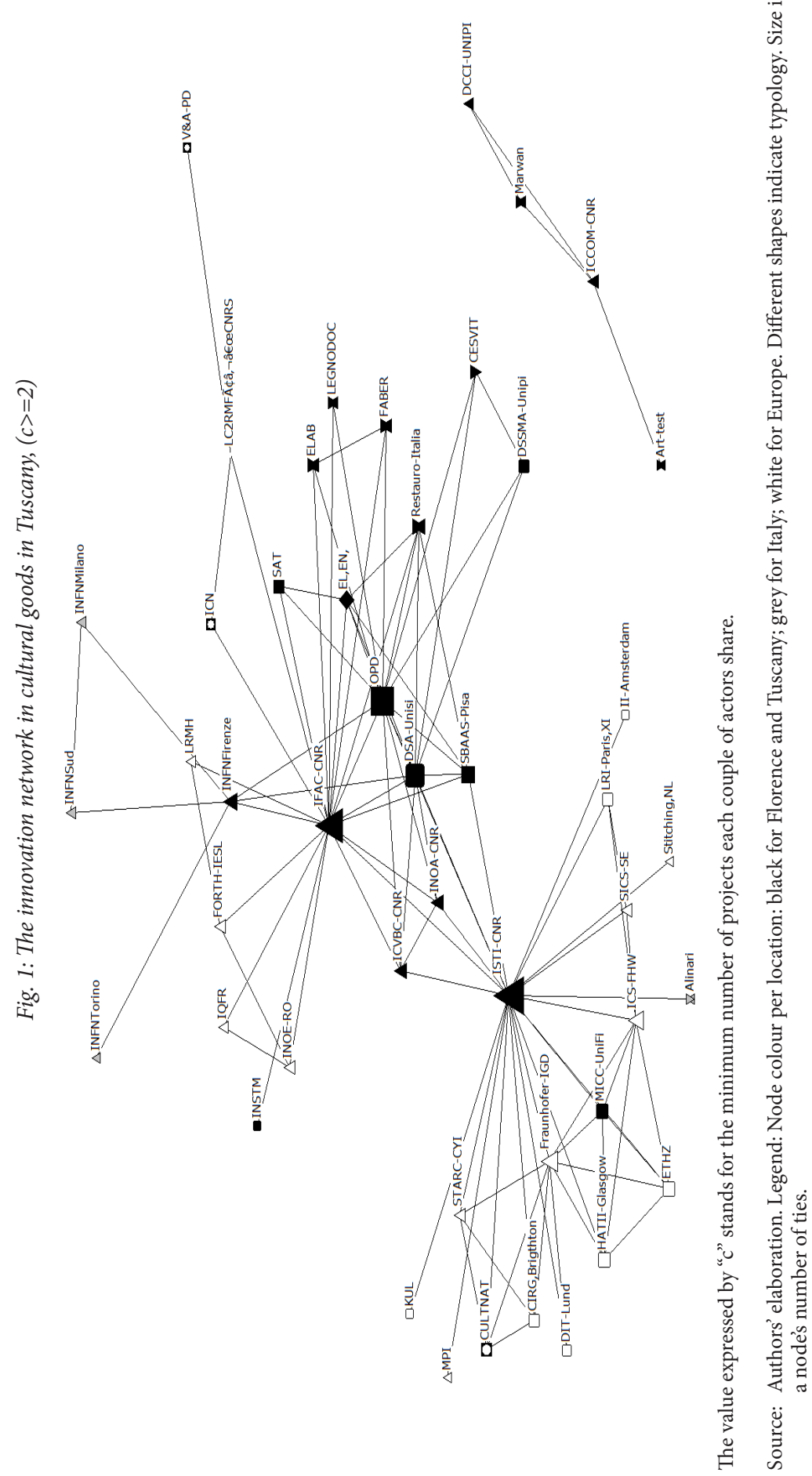


and organisations to form partnerships. This approach generates simulated networks, which can then be compared to the observed network in order to statistically assess network properties.

In contrast to the quite restrictive log-linear approach to modelling network dynamics (e.g. Wasserman and Faust, 1994), ERGMs are able to jointly analyse multiple variables as endogenous structural effects, such as tendencies toward transitivity, etc., and permitting a goodness-of-fit.

\subsection{Variables of the model}

The various meanings of proximity as a driver of the inter-firm cooperation have been converted into the variables which are represented in Table 1.

Geographical proximity is determined according to a co-location of the two actors forming a pair. This effect is also divided into four classes on the basis of partners' location in the municipality of Florence, in the Tuscan region, Italy or Europe.

Cognitive proximity occurs when organisations share the same kind of knowledge. Each firm and organisation is classified on the basis of its role in the project and in respect to its scientific domain (environmental, chemistry, conservation, diagnostics, physics, ICT, optoelectronics, restoration, 3D visualization). These are, in other words, the scientific domains of the actors related to the HTCG.

Institutional proximity is usually defined as when organisations have the same institutional form according to the Triple Helix Model, (Etzkowitz and Leydesdorff, 2000) as described in Balland (2012). Therefore, we classify actors on the basis of the following classes: research centres, institutions, small and large firms and universities.

Social proximity is then measured with the concept of triads (triadic closure) according to social network analysis and as in other contributions (Giuliani, 2013). It designates a closure process that takes place whenever at least three partners in a triad (or triangle) cooperate.

Tab. 1: Variables of the model

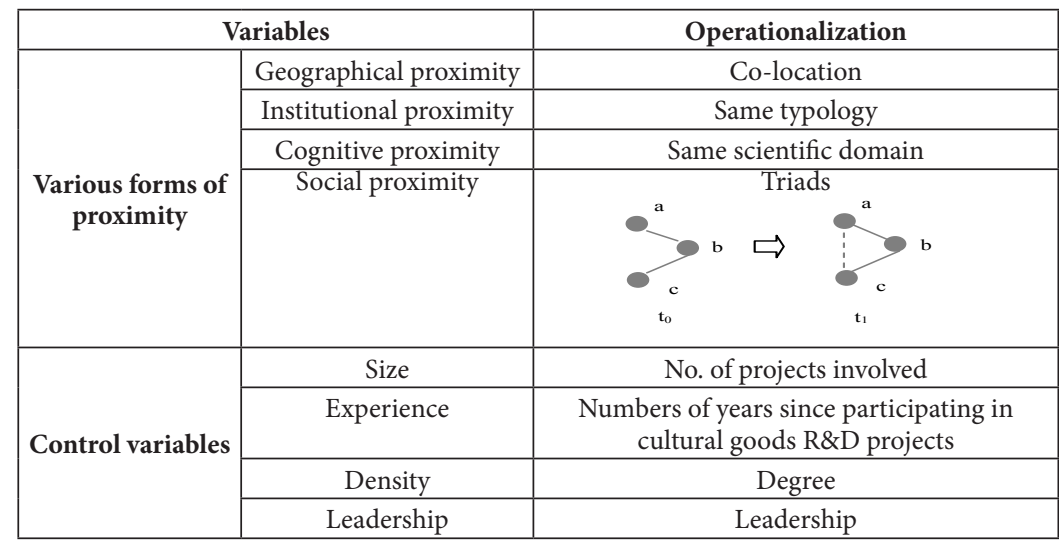

Source: our elaboration 
sinergie Vol. 34, N. 101, 2016

As previously noted, we do not investigate organizational proximity as firms of the same group were not allowed to participate in the selected research projects and it was not relevant in this specific research context. The organisation's attributes are also considered as control variables: experience in cultural goods projects (number of years), size (number of involved R\&D projects) and, finally, the role of the project leader.

\subsection{Estimation results}

Estimations are made using the R software and the StatNET-ERGM package (Hunter et al., 2008). The results are satisfactorily achieved in all models with specific differences that will be discussed below. The used procedure involves a step-wise search for the most significant and complex model.

Estimations are presented in Table $2^{6}$. Model 1 includes only the standard variable in the ERGM, that is, the existence of ties (edges). This is a single-parameter model, i.e., the simplest one, that posits an equal probability for all edges in the network, and it is not relevant in our case.

Beginning with Model 2, other variables are inserted. First, triads for social proximity are inserted, then location, related to geographical proximity; typology, related to institutional proximity; and, last, competences, related to cognitive proximity. Finally, the control variables are investigated, i.e., experience, number of project participations, role of project leader and SNA degree. The results of the Bayesian information criterion (BIC) and Akaike information criterion (AIC) tests follow a decreasing trend, suggesting an improvement of the model's significance and accuracy. Unfortunately, the variable for social proximity, i.e. triads, causes problems of collinearity if estimated with other variables, more so than if it is estimated only with edges. This is also highlighted from significance tests that are lower if this variable is included. A goodness-offit to the real network has been carried out as also advised by Hunter $e t$ al. (2008).

Social (network) proximity has been analysed through triads according to the concept of triadic closure ${ }^{7}$, which designates a closure process that takes place whenever at least two partners in a triad (triangle) have cooperated. Consequently, this means that, over time, the most frequent partners of one's partners are destined to become one's own partners and that firms interact with closer actors in terms of relational distance instead of moving away from their network of action. Unfortunately, this variable causes some problems with collinearity, and it is estimated without other forms of proximity.

If we look at the various kinds of proximity first, we find that geographical proximity is significant and positive. This means that actors

$6 \quad$ The estimates of parameters are interpreted on the basis of the gap between the network under study and a totally random network. In other words, a positive parameter indicates that the level of presence for the factor is higher in the examined network compared to a casual network.

7 This concept indicates that, if A has two unconnected partners, B and C, the latter are probably going to build a relationship, thus closing the open triangle. 
tend to develop partnerships with geographically close associates and it confirms the significant role of clustering in HTCGs because actors search for missing competences within the local cluster before turning to outside (cluster) experts.

Institutional proximity is positive as well, although the related parameter is lower than the previous one. It indicates that actors generally enter into partnerships with associates who belong to the same typology: firms with firms and research centres with research centres, etc. This is an unexpected outcome, since one would assume a stronger cooperation between heterogeneous actors aiming at solving complex issues in the implementation of new products or services, and not least because of the business under study, in which heterogeneous partnerships often develop innovation among agents of the triple helix.

Cognitive proximity is significant and positive, and this underlines that firms usually develop partnerships within the same scientific domain. This means that actors are more used to forming ties with other actors with whom they share the same knowledge base and competences. This could be relevant for funded R\&D networks where innovations are more incremental than radical innovation among cognitively closed partners.

As for the values of the parameters, being all dummies, they can be compared with each other. The highest value is that of cognitive proximity, followed by geographical proximity, social (network) proximity and, finally, institutional proximity; this lowest parameter was expected to be negative.

Tab. 2: ERGM Estimations

\begin{tabular}{|c|c|c|c|c|c|c|c|}
\hline \multicolumn{2}{|l|}{ Variables } & Model 1 & Model 2 & Model 3 & Model 4 & Model 5 & Model 6 \\
\hline \multicolumn{2}{|l|}{ Edges } & $\begin{array}{c}-2.280^{* * *} \\
(0.018)\end{array}$ & $\begin{array}{l}-7.4480 \\
(0.4261)\end{array}$ & $\begin{array}{l}-2.839^{* * *} \\
(0.0292)\end{array}$ & $\begin{array}{l}-2.981^{\star * *} \\
(0.0317)\end{array}$ & $\begin{array}{c}-3.190^{* * *} \\
(0.0033)\end{array}$ & $\begin{array}{l}-5.718^{* * *} \\
(0.0862)\end{array}$ \\
\hline $\begin{array}{l}\text { Geographical } \\
\text { proximity }\end{array}$ & Same location & & & $\begin{array}{l}1.1560^{\star * *} \\
(0.0378)\end{array}$ & $\begin{array}{c}1.1457^{* * *} \\
(0.0379)\end{array}$ & $\begin{array}{l}1.1050^{* * *} \\
(0.0387)\end{array}$ & $\begin{array}{c}1.0192^{\star * *} \\
(0.446)\end{array}$ \\
\hline $\begin{array}{l}\text { Institutional } \\
\text { proximity }\end{array}$ & Same typology & & & & $\begin{array}{c}0.5525^{* * *} \\
(0.0403)\end{array}$ & $\begin{array}{l}0.4072^{\star *} \\
(0.0418)\end{array}$ & $\begin{array}{c}0.3510^{* * *} \\
(0.0456)\end{array}$ \\
\hline $\begin{array}{l}\text { Cognitive } \\
\text { Proximity }\end{array}$ & $\begin{array}{l}\text { Same } \\
\text { competences }\end{array}$ & & & & & $\begin{array}{l}1.5170^{* * *} \\
(0.0442)\end{array}$ & $\begin{array}{c}1.3722^{\star * *} \\
(0.0503)\end{array}$ \\
\hline Social proximity & Triads & & $\begin{array}{c}0.9641^{\star * *} \\
(0.020)\end{array}$ & & & & \\
\hline \multirow{4}{*}{$\begin{array}{l}\text { Firms or } \\
\text { organisation 's } \\
\text { attributes }\end{array}$} & $\begin{array}{l}\text { Experience } \\
\text { (years) }\end{array}$ & & & & & & $\begin{array}{c}0.0215^{\star * *} \\
(0.0043)\end{array}$ \\
\hline & No. project & & & & & & $\begin{array}{c}0.0696^{* * *} \\
(0.0147)\end{array}$ \\
\hline & Leader & & & & & & $\begin{array}{c}-0.0814^{\star * *} \\
(0.0136)\end{array}$ \\
\hline & Degree & & & & & & $\begin{array}{c}0.0334^{\star * *} \\
(0.0000)\end{array}$ \\
\hline \multirow[t]{2}{*}{ Tests } & AIC & 21.935 & 32.667 & 20.966 & 20.790 & 19.757 & 16.843 \\
\hline & BIC & 21.943 & 32.684 & 20.983 & 20.815 & 19.791 & 16.911 \\
\hline
\end{tabular}

Source: Authors' elaborations. Standard error in brackets. ${ }^{* *}$ : significance at 0.01 level.

When we come to the analysis of control variables, we find that more experienced partners with greater planning ability usually have more relationships. Notwithstanding this, in one model (N. 6), the number of project participations is very close to zero. Even the role of the project leader
Francesco Capone Luciana Lazzeretti Interorganisational networks and proximity: an analysis of R\&D networks for cultural goods 
sinergie Vol. 34, N. 101, 2016

is close to zero, but on the negative side, which means that having played a coordinating role in the past does not always lead to a central position in future relationships.

Model 6 is the most adequate model in terms of test results. Its different parameters are graphically represented in Figure 2, together with the parameters of the social proximity of triads (Model 2). Figure 2 shows, at a glance, all the estimated parameters for the different kinds of proximity.

Fig. 2: Graphical representations of estimated parameters

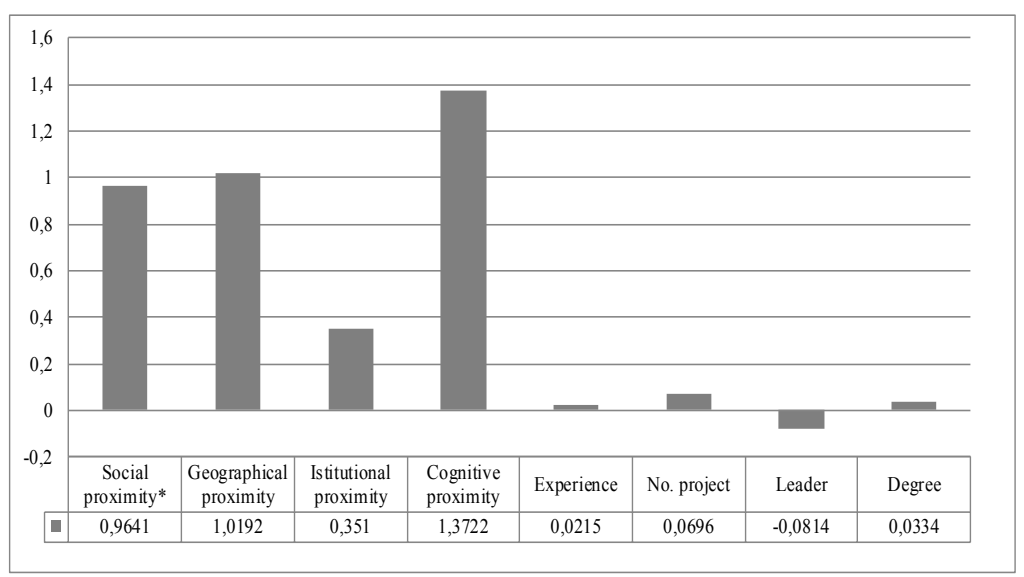

Source: Authors' elaborations. ${ }^{*}$ : Estimations from Model 2.

\section{Conclusions and discussion}

The aim of the present work was to investigate inter-organisational innovation networks, specifically regarding how innovation networks have been formed over a period of 15 years.

Our intent is to support the decision-making process involved in the choice of partners by analysing the strategic role of proximity. We adopt a new statistical method of analysis useful to study large and complex networks at a certain point in time, such as those of physics, chemistry and ICT that can be found in HTCG.

The methodology turns out to be an interesting tool for analysing and measuring the typologies of proximity in a large network of 267 actors and more than 6,500 relationships, which is not possible to analyse visually like in a graph (see for instance Appendix 1). Another positive contribution is that the ERGM also allows statistical estimation of the used parameters to obtain a goodness-of-fit of the model. The results are of relevant interest and help to deepen our knowledge on innovation networks formation and in particular in the HTCG business.

Various forms of proximity are then presented in their order of importance. Cognitive proximity is the most important of the parameters, ranking first. It indicates that actors tend to associate with partners with whom they share the same knowledge base, which facilitates smooth communication and exchange of information. 
This is somehow contrary to the idea of the strength of weak ties, according to which relevant knowledge for innovation of a more radical nature is the farthest from the usual sources. A further interpretation can be that when an organization collaborates with well-known partners, Francesco Capone Interorganisational networks and proximity: an analysis of R\&D these collaborations assume routine characteristics and, as a result, do not produce very innovative projects. In this study, this is difficult to ascertain this because empirical analysis cannot provide such in-depth insight.

Geographical proximity results represent the second most important of all proximity parameters. This underlines the relevance of innovation in the network under examination and the important role played in the Tuscan setting by both the cluster and the geographical closeness of the innovation partners. When looking for new partners with the aim of creating an innovation network, the first step is usually to try to find them in the local cluster - in which trust relationships and social capital already exist - and, only if not available, to search for them among more distant actors. The need for external competences can be due to different reasons: for example, of the specific competences that are necessary to participate in a European innovation project within the new Horizon 2020 Framework Program, which expressly requires international partnerships.

Social proximity is also positively correlated with the creation of innovation networks. In this study, we analyse triads in order to explore the relational behaviour of actors. Triads have a positive and high parameter, which suggests that the formation of innovation partnerships takes shape among partners of partners, since trust-building and experience processes with those partners have already been established in other or previous innovation networks.

Finally, as concerns institutional proximity, the estimations show that it is also positively correlated with the creation of innovation networks. This result is unexpected given that, in this business, firms establish many partnerships with research centres and universities, whereas the analysed networks show a tendency to enter into partnerships with similar actors. In fact, what emerges from the analysis of the various networks is that firms create partnerships with other firms and only a few research institutions, which, in turn, build relationships with each other. In other words, institutional proximity points to homogeneity of relationships.

The analysis of various forms of proximity partially confirm the idea that analysed formal innovation networks are mainly based on incremental innovations and on networks with knowledge redundancy.

Regarding managerial implications, the results prove that innovation networks in a complex business, such as that of HTCG, are developed by incremental processes, through the application of new products and procedures that are already implemented in other contexts (chemistry, physics, etc.) to cultural goods. Consequently, firms and managers should primarily focus on the creation of strong networks based on the competences of their original scientific domain, hence exploiting the cognitive proximity shared by actors. Then, firms should move beyond their own network of action and habitual contacts in order to undertake paths for developing more radical innovation stances. 
sinergie Vol. 34, N. 101, 2016

As far as the limits of the research are concerned, further research on proximity should be developed as its different forms are not always perceived unanimously in the literature. Some contributions discuss the term technological proximity which is explained as the need to access specific expertise (Knoben and Oerlemans, 2006). This issue is particularly relevant for our analysis as, in $\mathrm{R} \& \mathrm{D}$, this has become increasingly important because of global accessibility. The case of this study is pertinent to R\&D management but deserves further, more in-depth analysis. Preliminary results underline the relevance of geographical proximity, but it is the client or project base that is geographically fixed, not the potential technology suppliers. Further analysis should investigate this aspect.

Finally, this analysis is mainly static as it focuses on a specific instant in time at the end of the period of analysis. In this context, a longitudinal exploration of the innovation networks would be useful to verify whether results change at different stages in the course of development.

\section{References}

AHUJA G., POLIDORO J.R., MITCHELL W. (2009), "Structural homophily or social asymmetry? The formation of alliances by poorly embedded firms", Strategic Management Journal, vol. 30, pp. 941-958.

BAGLIERI D., BELUSSI, F., ORSI L. (2016), "Partnering strategies in biotech firms", in Belussi F., Orsi L. (2016), Innovation, Alliances, and Networks in High-Tech Environments, Routledge, London, pp. 66-85.

BALLAND P.A. (2012), "Proximity and the evolution of collaboration networks: Evidence from research and development projects within the Global Navigation Satellite System (GNSS) industry", Research Policy, vol. 46, n. 6, pp. 741-756.

BATHELT H., MALMBERG A., MASKELL P. (2004), "Clusters and knowledge: local buzz, global pipelines and the process of knowledge creation", Progress in Human Geography, vol. 28, n. 1, pp. 31-56.

BELL G.G. (2005), "Clusters, networks, and firm innovativeness", Strategic Management Journal, vol. 26, pp. 287.

BEN LETAIFA S., RABEAU Y. (2013), “Too close to collaborate? How geographic, proximity could impede entrepreneurship and innovation", Journal of Business Research, vol. 66, n. 10, pp. 2071-78.

BERGENHOLTZ C., WALDSTRØM C. (2011), "Inter-Organizational Network Studies - A Literature Review", Industry and Innovation, vol. 18, n. 6, pp. 539-562.

BONACCORSI A., PICCALUGA A. (1994), "A theoretical framework for University-Industry relations”, R\&D Management, vol. 24, n. 3, pp. 229247.

BOSCHMA R. (2005), "Proximity and innovation: A critical assessment", Regional Studies, vol. 39, n. 1, pp. 61-74.

BROEKEL T., HARTOG M. (2013), "Explaining the structure of interorganizational networks using exponential random graph models", Industry and Innovation, vol. 20, n. 3, pp. 277-295. 
CAMPANELlA F., DELlA PERUTA M.R., BRESCIANI S., DEZI L. (2016), "Quadruple Helix and firms' performance: an empirical verification in Europe", The Journal of Technology Transfer, first-on-line, pp. 1-18, doi:10.1007/s10961-016-9500-9.

CANTU C. (2010), "Exploring the role of spatial relationships to transform knowledge in a business idea-Beyond a geographic proximity", Industrial Marketing Management, vol. 39, n. 6, pp. 887-897.

CAPALDO A. (2015), Strategia, reti di imprese e capacità relazionali, Cedam, Padova.

CAPALDO A., PETRUZZELli A.M. (2014), "Partner Geographic and Organizational Proximity and the Innovative Performance of KnowledgeCreating Alliances", European Management Review, vol. 11, n. 1, pp. 63-84.

CAPONE F. (2016), Open innovation, dinamiche relazionali e strategia, Giappichelli, Torino.

CASANUEVA C., CASTRO I., GALÁN J.L. (2013), "Informational networks and innovation in mature industrial clusters", Journal of Business Research, vol. 66, n. 5, pp. 603-613.

CASPRINI E., PUCCI T., ZANNI L. (2014), "Business model shifts : a case study on firms that apply high technology to cultural goods", Technology Analysis and Strategic Management, vol. 26, n. 2, pp. 171-187.

COHEN W.M., LEVINTHAL D.A. (1990), "Absorptive capacity: a new perspective on learning and innovation", Administrative Science Quarterly, vol. 35, pp. 128-153.

CONTRACTOR N.S., WASSERMAN S., FAUST K. (2006), “Testing Multitheoretical, Multilevel Hypotheses about Organizational Networks", The Academy of Management Review, vol. 31, n. 3, pp. 681-703.

DAGNINO G.B., LEVANTI G., MINA' A., PICONE P.A. (2015), "Interorganizational network and innovation: a bibliometric study and proposed research agenda", Journal of Business and Industrial Marketing, vol. 30, n. 3/4, pp. 354 - 377.

DE STEFANO D., ZACCARIN S. (2013), "Modelling multiple interactions in science and technology networks", Industry and Innovation, vol. 20, n. 3, pp. 221-240.

DEZI L., SIMONI M., SCHIAVONE F. (2011), "Competitività dei cluster europei e localizzazione dell'attività brevettuale: un'indagine empirica”, Sinergie, n. 83, pp. 99-115.

ETZKOWITZ H., LEYDESDORFF L. (2000), "The Dynamics of Innovation: From National Systems and "Mode 2" to a Triple Helix of University-IndustryGovernment Relations", Research Policy, vol. 29, n. 2, pp. 109-123.

FRENKEL A., ISRAEL E., MAITAL S. (2015), "The evolution of innovation networks and spin-off entrepreneurship: The case of RAD”, European Planning Studies, vol. 23, n. 8, pp. 1646-1670.

GIULIANI E. (2013), "Network dynamics in regional clusters: Evidence from Chile", Research Policy, vol. 42, n. 8, pp. 1406-1419.

GRANOVETTER M. (1973), "The strength of weak ties", American Journal of Sociology, vol. 78 , n. 6, pp. 1360-1380.

HUNTER D.R., HANDCOCK M.S., BUTTS C.T. GOODREAU S.M., MORRIS M. (2008), "ERGM: A Package to Fit, Simulate and Diagnose ExponentialFamily Models for Networks", Journal of Statistical Software, vol. 24, n. 3, pp. $1-29$. 
HOHBERGER J. (2014), "Searching for emerging knowledge: the influence of collaborative and geographically proximate search", European Management Review, vol. 11, n. 2, pp. 139-157.

IRPET (2012), Il settore dellalta tecnologia applicata ai beni culturali in Toscana, IRPET, Firenze.

JOHANSON M., LUNDBERG H. (2007), "The impact of geographical proximity and technology on firms' R\&D operations”, Finanza, Marketing $e$ Produzione, n. 1, pp. 123-138.

KASTELLE T., STEEN J. (2014), “Networks of innovation”, in Dodgson M., Gann D.M., Phillips N. (Ed.), The Oxford Handbook of Innovation Management (pp. 102-120), Oxford University Press, Oxford, UK.

KNOBEN J., OERLEMANS L.A.G. (2006), "Proximity and inter-organizational collaboration: A literature review", International Journal of Management Reviews, vol. 8, n. 2, pp. 71-89.

LAZZERETTI L., CAPONE F. (2016), "R\&D networks in High Technology applied to Cultural Goods. A Social Network Analysis", Sinergie, vol. 34, n. 99, pp. 75-99.

LAZZERETTI L., CAPONE F., CINTI T. (2011), "Open innovation in city of art: The case of laser in conservation of artworks in Florence", City, Culture and Society, vol. 2, n. 3, pp. 159-68.

LOVE J.H., ROPER S. (2009), “Organizing innovation: complementarities between cross-functional teams", Technovation, vol. 29, n. 3, pp. 192-203.

LUSHER D., KOSKINEN J., ROBINS G. (2013), Exponential Random Graph Models for Social Networks: Theory, Methods, and applications, Cambridge University Press, Cambridge.

MCPHERSON M., SMITH-LOVIN L., COOK J.M. (2001), "Birds of a Feather Homophily in Social Networks", Annual Review of Sociology, vol. 27, n. 1, pp. 415-44.

MOLINA-MORALES F.X., GARCÍA-VILLAVERDE P.M., PARRA-REQUENA G. (2014), "Geographical and cognitive proximity effects on innovation performance in SMEs: a way through knowledge acquisition", International Entrepreneurship Management Journal, vol. 10, n. 2, pp. 231-251.

MOLINA-MORALES F.X., BELSO-MARTINEZ J.A., MAS-VERDÜ F., MARTINEZ-CHÀFER L. (2015), "Formation and dissolution on interfirm linkages in lengthy and stable networks in clusters", Journal of Business Research, vol. 68, n. 7, pp. 1557-1562.

MORRISON A., BALLAND P.A., BELSO-MARTÍNEZ A.J. (2014), “The Dynamics of Technical and Business Networks in Industrial Clusters: Embeddedness, status or proximity?", Papers in Evolutionary Economic Geography, n. 14.12, Utrecht University.

MUSCIO A. (2006), "Patterns of innovation in industrial districts: an empirical analysis", Industry and Innovation, vol. 13, n. 3., pp. 291-312.

NOOTEBOOM B. (2000), Learning and Innovation in Organizations and Economies, Oxford University press, Oxford.

PICCALUGA A., CESARONI F. (2003), (eds), Distretti industriali e distretti tecnologici. Modelli possibili per il Mezzogiorno, Franco Angeli, Milano.

PINA-STRANGER A., LAZEGA E. (2010), "Inter-organisational collective learning: the case of biotechnology in France", European Journal of International Management, vol. 4, n. 6, pp. 602-620. 
POWELL W.W., GRODAL S. (2005), "Networks of Innovators", in Fagerberg J., Mowery D.C., Nelson R.R. (eds), The Oxford Handbook of Innovation, Interorganisational Oxford University Press, Oxford, pp. 56-85.

PRESUTTI M., BOARI C., MAJOCCHI A. (2011), “The Importance of Proximity networks and proximity: an analysis of $R \& D$ for the Start-Ups' Knowledge Acquisition and Exploitation”, Journal of Small Business Management, vol. 49, n 3, pp. 361-389.

RITTER T., GEMUNDEN H.G. (2003), "Inter-organizational relationships and networks: An overview", Journal of Business Research, vol. 56, n. 9, pp. 691697.

RULLANI E. (2013), “Territori in transizione: nuove reti e nuove identità per le economie e le società locali”, Sinergie, n. 91, pp. 141-163.

SALIMBENI R. (2012), "The Technology District for Cultural Heritage and Sustainable Cities in Tuscany", Salone dell"Arte e del Restauro di Firenze, $8^{\text {th }}$ November 2012, Florence.

SCIARELLI M., TANI M. (2014), "La Social Network Analysis per lo studio dell'innovazione nelle reti di imprese", Sinergie Quaderni, n. 17, pp. 87-104.

SNIJDERS T.A.B., VAN DE BUNT G.G., STEGLICH C. (2010), "Introduction to actor-based models for network dynamics", Social Networks, vol. 32, n. 1, pp. 44-60.

TALLMAN S., JENKINS M., HENRY N., PINCH S. (2004), "Knowledge, clusters, and competitive advantage", Academy of Management Review, vol. 29, n. 2, pp. 258-271.

TORRE A. (2011), "The role of proximity during long-distance collaborative projects. Temporary geographical proximity helps", International Journal of Foresight and Innovation Policy, vol. 73, n. 1, pp. 213-230.

VAN DER VALK T., GIJSBERS G. (2010), “The Use of Social Network Analysis in Innovation Studies: Mapping Actors and Technologies", Innovation: Management, Policy and Practice, vol. 12, n. 1, pp. 5-17.

WASSERMAN S., FAUST K. (1994), Social Network Analysis: Methods and Applications, Cambridge University Press, New York.

WASSERMAN S., PATTISON P. (1996), "Logit models and logistic regressions for social networks. I: An introduction to Markov graphs and $\mathrm{p}^{*}$, Psychometrika, vol. 60, n. 3, pp. 401-425.

ZANNI L., PUCCI T. (2012), "Capacità interne, relazioni esterne e performance in un cluster emergente: un'analisi empirica nel settore Life Sciences", Conference proceedings of the XXIV Sinergie Conference, 18-19 Ottobre 2012, Università del Salento (Lecce).

\section{Academic or professional position and contacts}

\section{Francesco Capone}

Researcher of Management

University of Florence - Italy

e-mail: francesco.capone@unifi.it

\section{Luciana Lazzeretti}

Full Professor of Management

University of Florence - Italy

e-mail: luciana.lazzeretti@unifi.it 


\section{sinergie}

italian journal of management

Vol. 34, N. 101, 2016
Appendix (file avvailable on line, www.sinergiejournal.it)
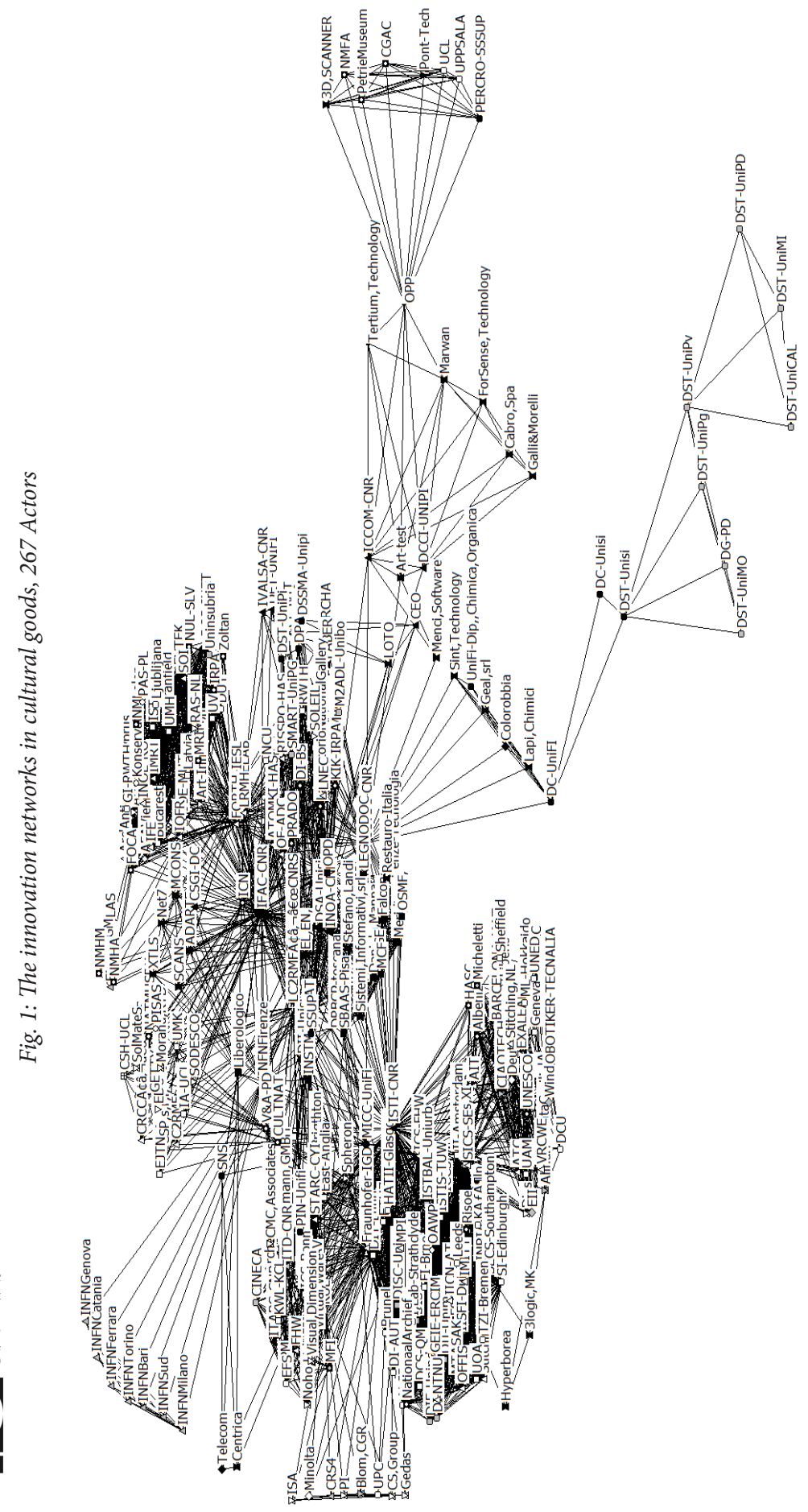